\title{
Anticancer effect of 20(S)-ginsenoside Rh2 on HepG2 liver carcinoma cells: Activating GSK-3 $\beta$ and degrading $\beta$-catenin
}

\author{
QINGQIANG SHI ${ }^{1,2 *}$, XUEPING SHI ${ }^{2 *}$, GEI ZUO ${ }^{3}$, WEI XIONG $^{2}$, HAIXING LI $^{2}$, \\ PEI GUO ${ }^{2}$, FEN WANG $^{2}$, YI CHEN ${ }^{2},{\text { JING } \mathrm{LI}^{2} \text { and DI-LONG CHEN }}^{2,4}$ \\ ${ }^{1}$ Emergency Department of First People's Hospital of Chongqing New North Zone, Chongqing 401121; \\ ${ }^{2}$ Laboratory of Stem Cell and Tissue Engineering, Department of Histology and Embryology and \\ ${ }^{3}$ Laboratory of Clinical Diagnostics, Chongqing Medical University, Chongqing 400016; \\ ${ }^{4}$ Chongqing Three Gorges Medical College, Chongqing 404120, P.R. China
}

Received April 12, 2016; Accepted August 4, 2016

DOI: $10.3892 /$ or.2016.5033

\begin{abstract}
S)-ginsenoside Rh2 [(S)Rh2] possesses potential to prevent cancer in vitro as well as in vivo, but the underlying mechanism is still unknown. First, we infected HepG2 cells with lentivirus which carries $\beta$-catenin. We detected the pharmacological effects of $(S) \mathrm{Rh} 2$ on HepG2 and HepG2- $\beta$-catenin cells and found that the $\mathrm{IC}_{50}$ of $(S) \mathrm{Rh} 2$ exposure on HepG2- $\beta$-catenin cells was higher than HepG2 cells. Flow cytometry (FCM) indicated that $(S) \mathrm{Rh} 2$ could be arrested in G0/G1 phase and induce early apoptosis in HepG2 and HepG2- $\beta$-catenin cells. Second, ELISA kit was used to check the activity of glycogen synthase kinase-3 $\beta$ (GSK-3 $\beta$ ), which was upregulated by $(S) \mathrm{Rh} 2$. GSK-3 $\beta$ inhibitor BIO, was used to verify that $(S) \mathrm{Rh} 2$ activated GSK-3 $\beta$. PCR and western blotting results indicated that $(S) \mathrm{Rh} 2$ could degrade the expression of $\beta$-catenin, which combined with TCF in the nucleus and activate transcription of Wnt target genes, such as Bax, Bcl-2, cyclin D1, MMP3, which were checked by chromatin immunoprecipitation (ChIP), PCR and western blotting. The results showed that the expression of Bax mRNA and proteins increased, while the cyclin D1, Bcl-2, MMP3 mRNA and proteins were downregulated in HepG2 and HepG2- $\beta$-catenin cells which was induced by $(S) \mathrm{Rh} 2$. By contrast, with the HepG2- $\beta$-catenin $+(S)$ Rh2 group, the expression of other mRNA and proteins in HepG $2+(S) \mathrm{Rh} 2$ group changed significantly. In vivo, experiments were performed using a nude mouse xenograft model to investigate the $(S) \mathrm{Rh} 2$ effect. So these results suggested that $(S) \mathrm{Rh} 2$ could suppress proliferation, promote apoptosis and inhibit metastasis of
\end{abstract}

Correspondence to: Dr Jing Li or Dr Dilong Chen, Laboratory of Stem Cell and Tissue Engineering, Department of Histology and Embryology, Chongqing Medical University, 1 Yixueyuan Road, Chongqing 400016, P.R. China

E-mail: 569258455@qq.com

E-mail: xinmengyuandlc@163.com

*Contributed equally

Key words: 20(S)-ginsenoside Rh2, glycogen synthase kinase-3 $\beta$, $\beta$-catenin, HepG2
HepG2, decrease weight of tumor by downregulating $\beta$-catenin through activating GSK-3 $\beta$ and the pharmacological effect of $(S) \mathrm{Rh} 2$ on HepG2 cells might be weakened by overexpression of $\beta$-catenin.

\section{Introduction}

Hepatocellular carcinoma (HCC) is one of the most common malignancies worldwide, which tends to metastasize within the liver and to the lung, brain and kidney (1-3). The incidence of HCC is increasing, especially in China, due to the high prevalence of hepatitis virus infection, which conveys a high risk of HCC $(4,5)$. Despite advances in diagnosis and treatment, HCC still ranks in the top three in cancer-associated mortality worldwide. Surgical resection is the first choice for most of HCC patients, but the overall survival rate 5 years after surgery remains $<12 \%(6-8)$. With the development of interventional treatment, chemotherapy drugs can directly act on hepatic carcinoma cells, so as to prolong the life of patients with liver cancer $(1,9)$. However, some of the HCC patients are not sensitive to chemotherapy and prone to resistance. For these patients, there is a lack of effective treatments. Therefore, related research focus on seeking effective drugs which can improve the effect of cancer chemotherapy.

Many studies have been focusing on utilizing ginseng as an option for HCC treatment $(10,11)$. The ginsenoside chemoprevention and anticancer effects are achieved through mechanisms such as DNA damage mitigation, apoptosis induction, proliferation inhibition positive and immunomodulation $(12,13)$. 20(S)-ginsenoside Rh2 [(S)Rh2] increases the proportion of SMMC-7721 cells in G1 phase, and decreases those in $\mathrm{S}$ and $\mathrm{G} 2 / \mathrm{M}$ phases (14). Moreover, $(S) \mathrm{Rh} 2$ downregulates the expression of positive regulating factors (cyclin D1 and E) and upregulates the expression of negative regulating factors (p16 protein, p21 mRNA) in SMMC-7721 cells (15). Many studies have shown that $(S)$ Rh2 acts upstream of glycogen synthase kinase-3 $\beta$ (GSK-3 $\beta$ ), on EGFR and Akt $(16,17)$. Inaction of Akt could result in decreased phosphorylation of GSK-3 $\beta$, leading to its activation (17). $(S) \mathrm{Rh} 2$ is one of the most widely investigated ginsenosides and exerts potent anticancer activity in vitro and in vivo (12). 
GSK- $3 \beta$ is a serine/threonine kinase that was first isolated and purified as an enzyme capable of phosphorylating and inactivating the enzyme glycogen synthase (18). We now know that, beyond its role in glycogen metabolism, GSK-3 $\beta$ acts as a downstream regulatory switch that determines the output of numerous signaling pathways initiated by diverse stimuli (19). GSK- $3 \beta$ has a high basal activity within the cell, and both insulin and Wnt stimulation lead to a decrease in kinase activity. In the case of insulin this is by activation of protein kinase B (PKB), which phosphorylates a serine residue in the $\mathrm{N}$ terminus, residues Ser-9 in GSK-3 and Ser-21 in GSK-3 $\alpha$, and inhibits GSK-3 activity (20). Wnt stimulation, on the other hand, acts on GSK-3 $\beta$ in a multiprotein complex that also includes axin, adenomatous polyposis coli (APC)-associated protein, and $\beta$-catenin. GSK-3 $\beta$ phosphorylates all three of these proteins; however, phosphorylation of $\beta$-catenin leads to its degradation. Wnt stimulation inhibits the activity of GSK-3 $\beta$ within this complex, through mechanisms that may involve axin binding to the proteins dishevelled and LRP-5 (21). This allows unphosphorylated $\beta$-catenin to accumulate in the cytoplasm and nucleus. By binding to TCF family transcription factors, nuclear $\beta$-catenin regulates transcription of target mRNAs such as c-Myc and cyclin D1 (22-24). Mutations, which perturb the function of the axin-APC complex, such as truncation of APC or deletion of the GSK-3 sites of $\beta$-catenin, are present in $90 \%$ of colon cancers. The pathways in which GSK-3 acts as a key regulator, when dysregulated, have been implicated in the development of human diseases such as diabetes, Alzheimer's disease, bipolar disorder and cancer (18).

It has been proven by substantial evidence that $(S) \mathrm{Rh} 2$ displays dramatic inhibitory effect on HepG2 cells, although its specific molecular mechanism has not been well understood. GSK-3 is apparently related to tumor progression. Therefore, we hypothesize that there may be some correlation between $(S) \mathrm{Rh} 2$ and GSK-3. Mechanism in such phenomena is that $(S) \mathrm{Rh} 2$ exerts its anticancer effects via GSK-3/ $\beta$-catenin pathway.

\section{Materials and methods}

Cell culture. HepG2 cells (Bogoo, Shanghai, China) cryopreserved in our laboratory were cultured in DMEM-F12 containing $10 \%$ fetal bovine serum (HyClone, Waltham, MA, USA), which does not contain antibiotics, in incubators with $5 \% \mathrm{CO}_{2}$, at $37^{\circ} \mathrm{C}$ and constant humidity.

Establishment and identification of HepG2- $\beta$-catenin cells. The lentivirus carrying $\beta$-catenin cells were constructed by Neuron Biotechnology Co., Ltd, which provided that multiplicity of infection was 20 and puromycin working concentration was $0.5 \mu \mathrm{g} / \mu \mathrm{l}$. The cells were seeded at a concentration of $2 \times 10^{5}$ cells $/ \mathrm{ml}$ and incubated in two disposable sterile bottles, at $37^{\circ} \mathrm{C}$, for $24 \mathrm{~h}$. The culture medium was discarded, and $\beta$-catenin lentiviral particles were added in a bottle with $50 \mu 1$ and $4 \mathrm{mg} / \mathrm{ml}$ of polybrene $1 \mu 1$, while in another bottle was added DMEM-F12. Laser scanning confocal microscopy, flow cytometry (FCM), PCR were used in observation. Stably expressed single clones were established by puromycin selection $(0.5 \mu \mathrm{g} / \mu \mathrm{l})$.
HepG2- $\beta$-catenin cells were established by our laboratory, which were cultured in DMEM-F12 containing $10 \%$ fetal bovine serum and puromycin $(0.5 \mu \mathrm{g} / \mu \mathrm{l})$.

Nude mouse xenograft model. Mice (BALB/c, 6-8 weeks old) were purchased from the Laboratory Animal Center of Chongqing Medical University. HepG2 and HepG2- $\beta$-catenin cells were injected into the mice. When the diameter of the new neoplasm was $0.5 \mathrm{~cm}$, the mice were given by gavage $(S) \mathrm{Rh} 2(20 \mathrm{mg} / \mathrm{kg})$ once a day for 20 days. The diameter of the new neoplasms and the weight were recorded every day.

Antibodies and chemicals. (S)Rh2 was purchased from the National Standard Network, with a purity of $98 \%$. Dimethylsulphoxide (DMSO), Cell Counting Kit-8 (Takara Bio, Inc., Shiga, Japan), and Annexin V-FITC notation apoptosis detection kit (KeyGen Biotech Co., Ltd., Nanjing, China) were used. The primary antibodies, GSK-3 $\beta(1: 1,000)$, $\beta$-catenin $(1: 1,000)$, MMP3 $(1: 1,000)$, TCF4 $(1: 100)$, were purchased from AB Antibody Technology. Bax $(1: 1,000)$, cyclin D1 $(1: 1,000)$ antibodies were purchased from Sigma Co. GSK-3 $\beta$ ELISA kit was purchased from Cell Signaling Technology, Inc. (Danvers, MA, USA). The chromatin immunoprecipitation (ChIP) and IHC kits were purchased from Cell Signaling Technology, Inc. The secondary antibodies were horseradish peroxidase (HRP)-conjugated goat anti-rabbit $\mathrm{IgG}$ and anti-mouse $\mathrm{IgG}$ antibodies (Beyotime Institute of Biotechnology, Shanghai, China).

CCK-8 assay. For detecting cell proliferation, a CCK-8 assay was performed. Briefly, $1 \times 10^{4}$ cells/well were plated in 96-well plates and cultured at different times. At the end of each time, $20 \mu \mathrm{l}$ CCK- 8 was added to each well and then incubated at $37^{\circ} \mathrm{C}$ for $3 \mathrm{~h}$. Then plates were detected by $450 \mathrm{~nm}$ on a spectrophotometric plate reader (Shanghai Precision \& Scientific Instrument Co., Ltd., Shanghai, China). Cells were treated with $0.1 \%$ DMSO which served as a solvent control. Complete culture medium without cells served as a blank control. All experiments were performed in triplicate. The drug concentration resulting in inhibition of growth $\left(\mathrm{IC}_{50}\right)$ to $50 \%$ was determined.

Cell cycle assay. The cells were seeded at a concentration of $2 \times 10^{5}$ cells $/ \mathrm{ml}$ and incubated for $24-72 \mathrm{~h}$ with $(S) \mathrm{Rh} 2$ at various concentrations. $(S) \mathrm{Rh} 2$ dissolved in DMSO was added to the medium in serial dilution. The cells were collected by centrifugation at 2,500 $\mathrm{x}$ g for $5 \mathrm{~min}$, fixed in $70 \%$ ethanol then washed once with PBS and resuspended in $1 \mathrm{ml}$ of PBS containing $2.5 \mu \mathrm{g} / \mathrm{ml}$ ribonuclease and $50 \mu \mathrm{g} / \mathrm{ml}$ propidium iodide (Beyotime Institute of Biotechnology), incubated in the dark for $30 \mathrm{~min}$ at room temperature and analyzed using FCM.

Apoptosis. Briefly, for the cell death assay, HepG2 and HepG2- $\beta$-catenin cells were seeded at a concentration of $2 \times 10^{5}$ cells $/ \mathrm{ml}$ and maintained for logarithmic growth by passaging them every $48-96 \mathrm{~h}$ and incubated for $48 \mathrm{~h}$ with $(S) \mathrm{Rh} 2$. Samples were prepared according to the instructions provided together with Annexin V apoptosis kit. Briefly, after treatment for the indicated time, cells were collected and washed twice with binding buffer containing $10 \mathrm{mM}$ HEPES, 
pH 7.4, $140 \mathrm{mM} \mathrm{NaCl}, 2.5 \mathrm{mM} \mathrm{CaCl}_{2}$. Then $1 \times 10^{5}$ cells were resuspended in $100 \mu \mathrm{l}$ of binding buffer. Last, $5 \mu \mathrm{l}$ of Annexin V-FITC and $10 \mu \mathrm{l}$ of propidium iodide $(50 \mu \mathrm{g} / \mathrm{ml}$, stocking concentration) were added to the cell suspension. Gently mixed, the cells were incubated for $15 \mathrm{~min}$ at room temperature, then $400 \mu \mathrm{l}$ of binding buffer was added to get the sample ready. Quantification of cell death was analyzed with a BD FACScan.

$H \& E$ coloration. First tissue blocks were fixed with formalin for $16 \mathrm{~h}$, after which they were embedded with paraffin and dewaxed with xylene. Then they were dehydrated with ethanol, after which they were stained with hematoxylin for $5 \mathrm{~min}$ and differentiated with ethanol of hydrochloric acid, then they were immersed in warm water for $15 \mathrm{~min}$, after which they were put in eosin solution for 2 min and dehydrated with ethanol again. Finally they were sealed with neutral resin.

ELISA analysis. The protein content of cell extracts was determined by the Bradford assay (Bio-Rad). A total of $10 \mathrm{ng}$ of protein was added in each well. The ELISA kit was used to assay activities of protein (Cell Signaling Technology, Inc.) according to the manufacturer's instructions.

Immunocytochemistry. Immunocytochemistry was performed to identify the subcellular localization of $\beta$-catenin, GSK-3 $\beta$, and MMP3. The tissues were permeabilized with $0.5 \%$ Triton $\mathrm{X}-100$ in PBS for $5 \mathrm{~min}$, and incubated with $3 \% \mathrm{H}_{2} \mathrm{O}_{2}$ to inactivate endogenous peroxidase. Blocking was carried out with goat serum for $1 \mathrm{~h}$ to minimize non-specific binding of the primary antibody. The $\beta$-catenin (1:100), GSK-3 $\beta$ (1:200), and MMP3 (1:100) antibodies were applied overnight, and washed three times with PBS. As a specific control, PBS was used instead of the primary antibodies to exclude non-specific binding of the secondary antibodies. After incubation with goat anti-rabbit secondary antibody for $1 \mathrm{~h}$, slides were rinsed for $5 \mathrm{~min}$ in PBS three times before application of the HRP-conjugated anti-goat antibody. Finally, immunocytochemical staining was visualized with 3,3'-diaminobenzidine (DAB) reagent. Images were acquired using an Olympus DX-51 microscope. The mean density values of the immunocytochemical stains were quantified by Image-Pro Plus (IPP) software.

ChIP-PCR. ChIP was performed by the Cell Signaling Technology ChIP assay kit with minor modifications. A total of $1.1 \times 10^{8}$ cells were incubated with $1 \%$ formaldehyde for $15 \mathrm{~min}$ and $0.125 \mathrm{M}$ glycine was added for $5 \mathrm{~min}$. Washed cells were incubated in NP-40 lysis buffer and nuclei pelleted, resuspended in sodium dodecyl sulfate lysis buffer and sonicated five times on ice. Precleared soluble chromatin was incubated with anti-TCF4, an isotype control, or no antibody followed by Protein G agarose/salmon sperm DNA. qPCR was performed on immune complex-associated DNA by primers spanning rs1876453 (5-GGAAAGTTTCTGTGCCGCGA-3, 5-GACAATCAGGACCAGGCGGT-3), SYBR-Green-based detection, and the Illumina Eco Real-Time PCR System. A standard curve was constructed by a chromatin input control.

Western blotting. The protein content of cell extracts was determined by the Bradford assay (Bio-Rad). A total of 20-30 $\mu \mathrm{g}$ of protein was electrophoresed on 10-15\% SDS-PAGE and transferred to PDVF membranes. Membranes were blocked and incubated with primary Abs at the appropriate concentration. Subsequently they were incubated with HRP-conjugated goat anti-rabbit IgG or goat anti-mouse IgG (1:2,000 dilutions; Bio-Rad). Labeled bands were detected by Immun-Star ${ }^{\mathrm{TM}}$ HRP Chemiluminescent Kit, and images were captured and the intensity of the bands was quantified by the Bio-Rad VersaDoc ${ }^{\mathrm{TM}}$ Imaging System (Bio-Rad, Regents Park, NSW, Australia).

\section{Reverse transcription-polymerase chain reaction (RT-PCR)} analysis. Total RNA was extracted by TRIzol reagent (Invitrogen). RT-PCR was carried out with M-MLV transcriptase and oligod(T) and the resulting cDNA products were used as templates for real-time PCR assays. Real-time RT-PCR was performed by the ABI PRISM 7700 Sequence Detection System (Applied Biosystems). A total of $25 \mu 1$ mixture was used for reaction. Fold change in mRNA expression was determined with the $2^{-\Delta \Delta C T}$ method with $\beta$-actin as endogenous control. Primer sequence was as follows: $\beta$-catenin forward, CGCCAGGGCGCCAGGGTTTTCCCAGTC and reverse, TAATACGACTCACTAGAGGG; GSK-3 $\beta$ forward, GGA TTCGTCAGGAACAGGACA and reverse, TTAGCATCT GACGCTGCTGT; Bcl-2 forward, GGTGAACTGGGG GAGGATTG and reverse, GGCAGGCATGTTGACTTCAC; Cyclin D1 forward, CATGGAGAGACAGACAGAGCA and reverse, TATCCACGGGGCTGTTCCTA; Bax forward, TTC ATCCAGGATCGAGCAGG and reverse, CTTGGTGGA CGCATCCTGAG; MMP3 forward, TAATGGAGATGC CCACTTTGATG and reverse, GAGTGAAAGAGACCC AGGGAGTG. After incubation at $5^{\circ} \mathrm{C}$ for $2 \mathrm{~min}$, then $95^{\circ} \mathrm{C}$ for $10 \mathrm{~min}$, the reaction was carried out for 40 cycles as follows: $95^{\circ} \mathrm{C}$ for $15 \mathrm{sec}$ and $60^{\circ} \mathrm{C}$ for $1 \mathrm{~min}$.

Statistical analysis. The intensity of the immunoreactive bands was determined by a densitometer (Bio-Rad, Hercules, CA, USA). The statistical significance of the differences between the control and treated samples was calculated by Student's t-test (SSPS 17.0). $\mathrm{P}<0.05$ was considered significant. All experiments were repeated at least three times, for each time with three or more independent observations.

\section{Results}

Identification of HepG2- $\beta$-catenin cells. Lentivirus carrying $\beta$-catenin was used to infect HepG 2 cells for 2 days. Laser scanning confocal microscopy was used for observation and it showed that cells emitted green fluorescence, which indicated that the HepG2 cells were successfully infected by lentivirus. Infection rate was analyzed by FCM which increased as time went on (Fig. 1A). The PCR was used for checking the expression of $\beta$-catenin and the results demonstrated that the expression of $\beta$-catenin in infected group was higher than that of the control group (Fig. 1B). So it was identified that HepG2 cells were infected by lentivirus carrying $\beta$-catenin, and were named HepG2- $\beta$-catenin cells.

Overexpression of $\beta$-catenin decreases the pharmacological effect of $(S) R h 2$. CCK-8 showed that ginsenoside $(S) \mathrm{Rh} 2$ can effectively inhibit the survival of HepG2 and HepG2- $\beta$-catenin 

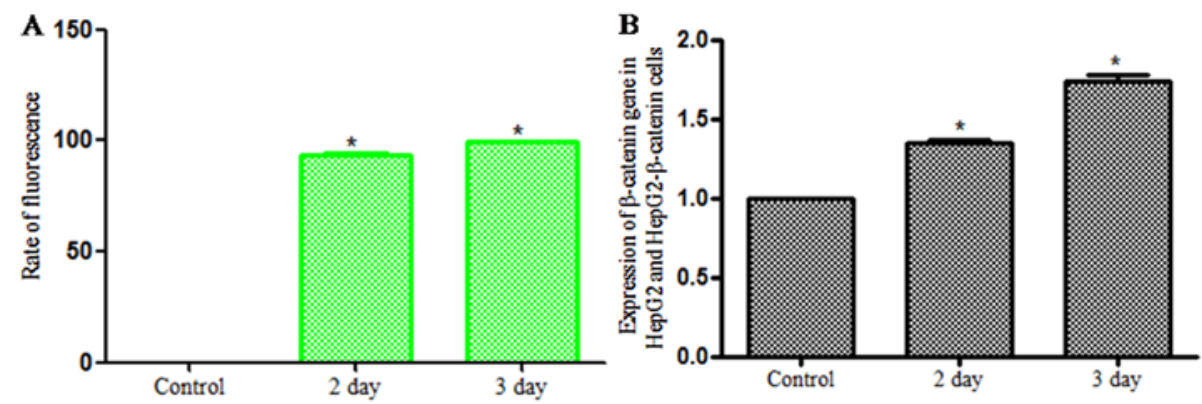

Figure 1. HepG2- $\beta$-catenin cells were identified. (A) The rate of infection was analyzed by FCM. (B) HepG2 cells were infected for 2 and 3 days. Expression of $\beta$-catenin mRNAs was measured by qRT-PCR. Results shown are representative of at least three independent experiments. "P<0.05 vs. control. FCM, flow cytometry.
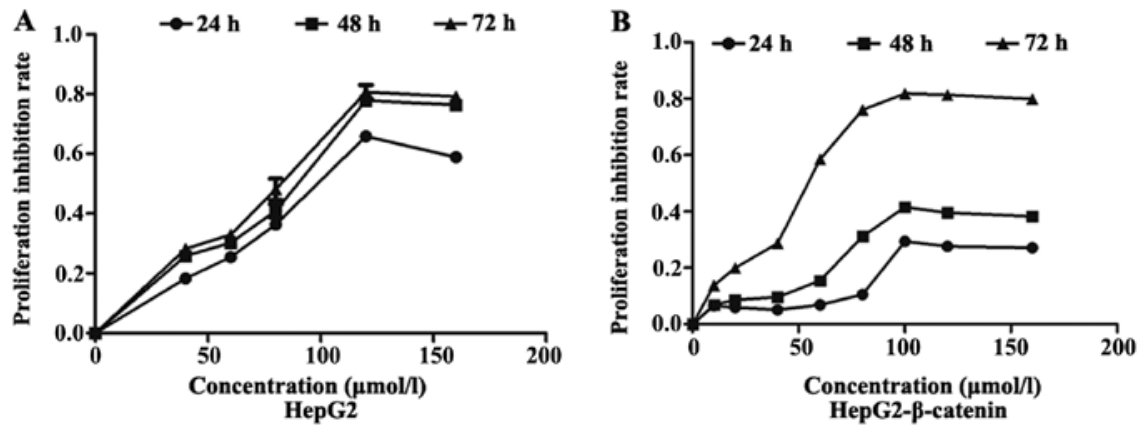

Figure 2. Growth studies. (A) HepG2 cells were incubated with $(S) \mathrm{Rh} 2$ for 24,48 and $72 \mathrm{~h}$, then assessed by the CCK- 8 assay. Cell growth was in a dose- and time-dependent manner. The $\mathrm{IC}_{50}$ of $(S) \mathrm{Rh} 2$ exposure on $\mathrm{HepG} 2$ cells for 48 and $72 \mathrm{~h}$ was 100 and $58.12 \mu \mathrm{mol} / 1$, respectively. (B) HepG2- $\beta$-catenin cells were incubated with $(S) \mathrm{Rh} 2$ for 24,48 and $72 \mathrm{~h}$, then assessed by the CCK-8 assay. Cell growth was in a dose- and time-dependent manner. The $\mathrm{IC}_{50}$ of $(S) \mathrm{Rh} 2$ exposure on HepG2- $\beta$-catenin cells for 48 and $72 \mathrm{~h}$ was 129.2 and $83.33 \mu \mathrm{mol} / 1$, respectively. Each point represents the mean $\pm \mathrm{SD}(\mathrm{n}=6)$. $(S) \mathrm{Rh} 2$, 20(S)-ginsenoside Rh2.
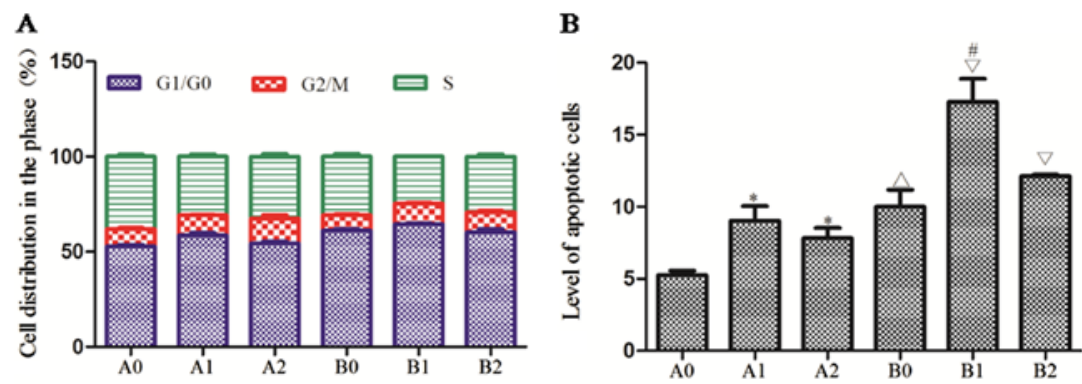

Figure 3. Cell cycle and apoptosis. (A) HepG2- $\beta$-catenin and HepG2 cell cycle arrest was induced for $48 \mathrm{~h}$ with $(S) \mathrm{Rh} 2$ or $(S) \mathrm{Rh} 2+\mathrm{BIO}$. Cell cycle distribution was analyzed by FCM. Green areas, S phase; red areas, G2/M phase; blue areas, G0/G1 phase of the cell cycle. Proportion of the cells is expressed as the mean $\pm \mathrm{SD}$ of three independent experiments. (B) Apoptosis in HepG2- $\beta$-catenin and HepG2 cells treated for $48 \mathrm{~h}$ with $(S) \mathrm{Rh} 2$ or $(S) \mathrm{Rh} 2+\mathrm{BIO}$ was measured by Annexin V-FITC/PI. Controls were treated with the appropriate vehicle. Duplicate samples were measured and representative experimental results are shown. A0, HepG2- $\beta$-catenin; A1, HepG2- $\beta$-catenin $+(S)$ Rh2; A2, HepG2- $\beta$-catenin + $(S) \mathrm{Rh} 2+\mathrm{BIO}$; B0, HepG2; B1, HepG2 + $(S)$ Rh2; B2, HepG2 + $(S)$ Rh2 + BIO. $(S)$ Rh2, 20(S)-ginsenoside Rh2; FCM, flow cytometry.

cells in vitro, which exhibited a dose-dependent manner at a range of $10-160 \mu \mathrm{mol} / 1(S) \mathrm{Rh} 2$. The $\mathrm{IC}_{50}$ of $(S) \mathrm{Rh} 2$ exposure on HepG2 cells for 48 and $72 \mathrm{~h}$ was 100 and $58.12 \mu \mathrm{mol} / 1$, respectively, and the $\mathrm{IC}_{50}$ of $(S) \mathrm{Rh} 2$ exposure on HepG2- $\beta$-catenin for 48 and $72 \mathrm{~h}$ was 129.2 and $83.33 \mu \mathrm{mol} / \mathrm{l}$, respectively. The $\mathrm{IC}_{50}$ of $(S) \mathrm{Rh} 2$ exposure on HepG2- $\beta$-catenin cells was higher than that on HepG2 cells. The effect of overexpression of $\beta$-catenin on cell cycle and apoptosis was detected by FCM which indicated that $(S) \mathrm{Rh} 2$ could arrest HepG2 and HepG2- $\beta$-catenin cells in G0/G1 phase. The cell population in $\mathrm{G} 0 / \mathrm{G} 1$ phase of the HepG2 group was $61.02 \pm 1.48 \%$, of the
HepG2 $+(S)$ Rh2 group $64.57 \pm 0.65 \%$, of the HepG2- $\beta$-catenin group $52.86 \pm 1.46 \%$, and of the HepG2- $\beta$-catenin $+(S) \mathrm{Rh} 2$ group $58.61 \pm 2.01 \%$. HepG2- $\beta$-catenin cells in G0/G1 phase $(52.86 \pm 1.46 \%)$ was significantly lower than that in the HepG2 group $(61.02 \pm 1.48 \%)$, which illustrated that the percentage of overexpression of $\beta$-catenin in $\mathrm{G} 0 / \mathrm{G} 1$ phase decreased so as to accelerate proliferation. The apoptotic rate of the HepG2 group was $10.01 \pm 2.02 \%$, of the HepG2 + $(S) \mathrm{Rh} 2$ group $17.27 \pm 2.77 \%$, of the HepG2- $\beta$-catenin group $5.26 \pm 0.50 \%$, and of the HepG2- $\beta$-catenin $+(S) \mathrm{Rh} 2$ group $9.02 \pm 1.76 \%$. The apoptotic rate of the HepG2- $\beta$-catenin $+(S) \mathrm{Rh} 2$ group was lower than 

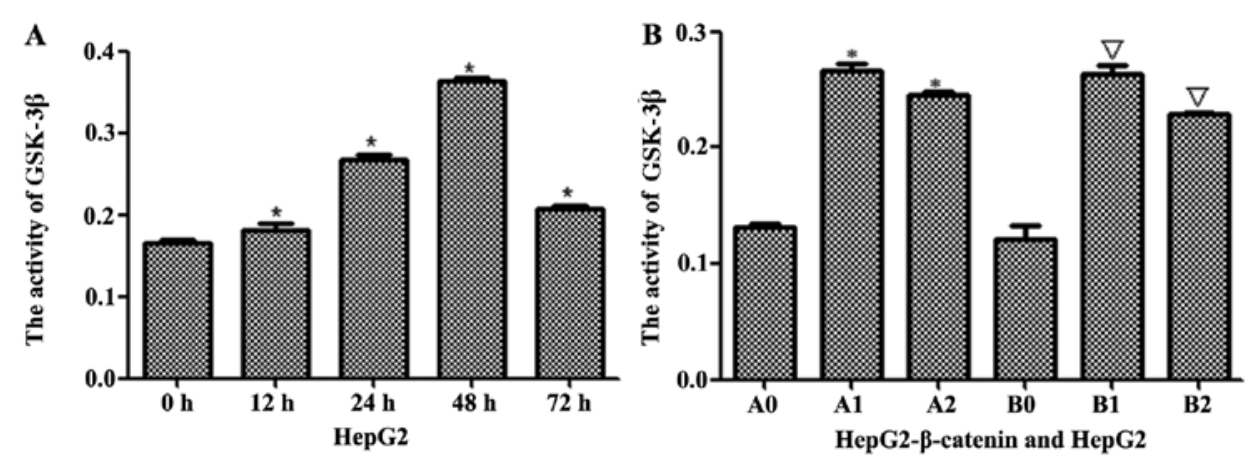

Figure 4. GSK-3 $\beta$ was activated by $(S)$ Rh2. (A) The activity of GSK-3 $\beta$ was checked by ELISA kit. In treatment group, the activity of GSK-3 $\beta$ increased in a time-dependent manner. (B) GSK-3 $\beta$ was activated by $(S) \mathrm{Rh} 2$ in HepG2- $\beta$-catenin and HepG2 cells. Results shown are representative of at least three independent experiments. ${ }^{\prime} \mathrm{P}<0.01, \mathrm{HepG} 2-\beta$-catenin $+(S)$ Rh2, shRNA- $\beta$-catenin-HepG2 $+(S)$ Rh $2+$ BIO vs. HepG2- $\beta$-catenin group; ${ }^{\Delta}$ p $<0.01$,

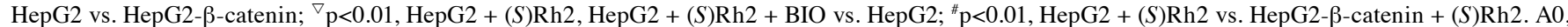
HepG2- $\beta$-catenin; A1, HepG2- $\beta$-catenin + $(S)$ Rh2; A2, HepG2- $\beta$-catenin + $(S)$ Rh2 + BIO; B0, HepG2; B1, HepG2 + $(S)$ Rh2; B2, HepG2 + $(S)$ Rh2 + BIO GSK-3 $\beta$, glycogen synthase kinase-3 $\beta ;(S)$ Rh2, 20(S)-ginsenoside Rh2.
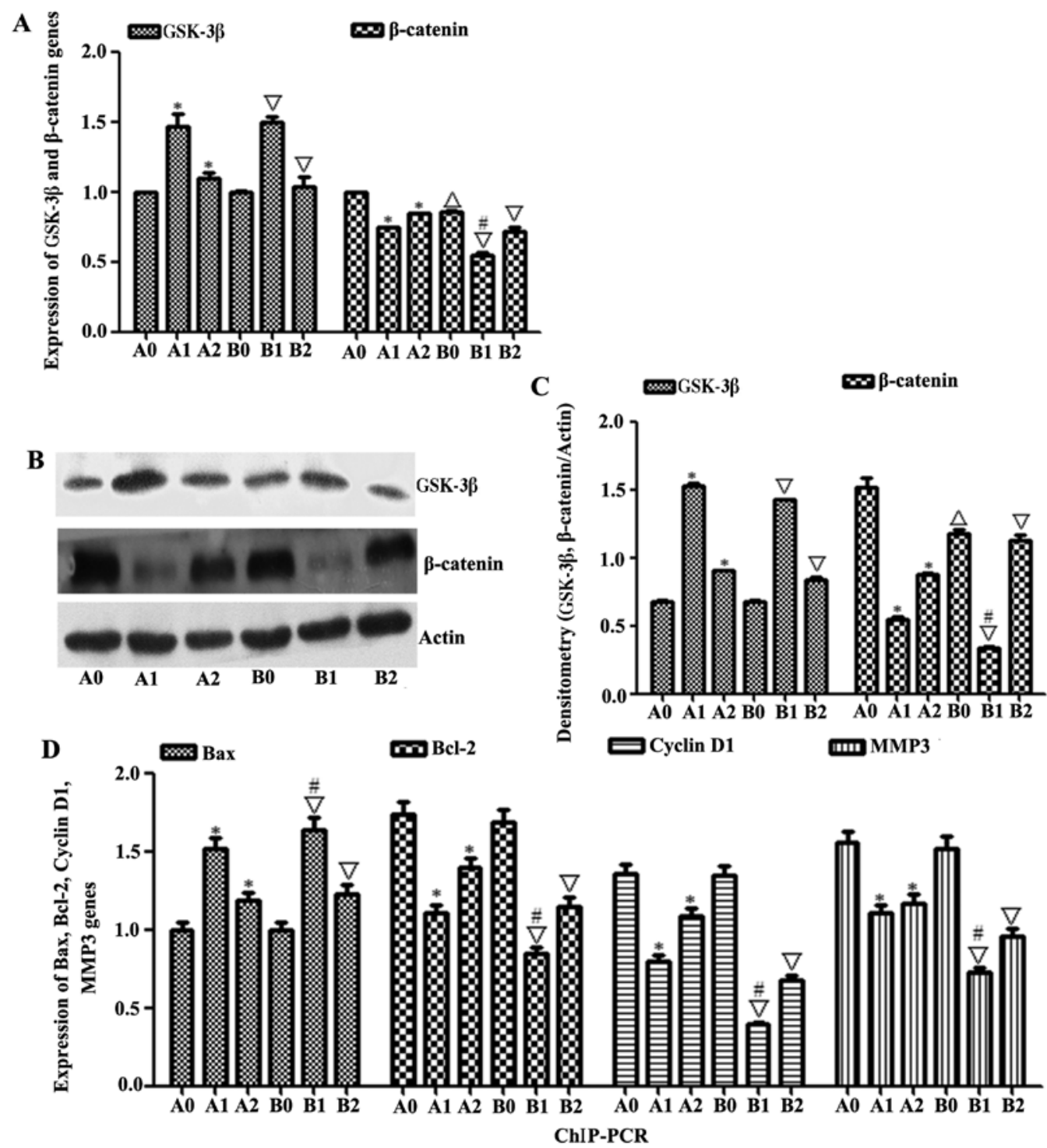

Figure 5. The expression of $\beta$-catenin was degraded through activating GSK-3 $\beta$ and ChIP-PCR. (A) The expressions of GSK-3 $\beta$ and $\beta$-catenin mRNAs were measured by qRT-PCR. (B and C) GSK-3 $\beta$ and $\beta$-catenin expression levels were determined by western blotting; $\beta$-actin served as a protein loading control (D) The expressions of Bax, Bcl-2, cyclin D1 and MMP3 mRNAs were measured by PCR. Results shown are representative of at least three independent experiments. "P<0.01, HepG2- $\beta$-catenin $+(S)$ Rh2, shRNA- $\beta$-catenin-HepG2 $+(S)$ Rh2 + BIO vs. HepG2- $\beta$-catenin group; ${ }^{\circ}$ < $<0.01$, HepG2 vs. HepG2- $\beta$-catenin;

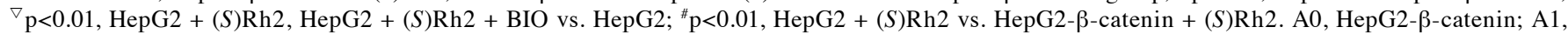

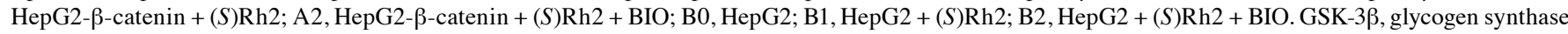
kinase-3 $\beta$; ChIP, chromatin immunoprecipitation; $(S) \mathrm{Rh} 2,20(S)$-ginsenoside Rh2. 

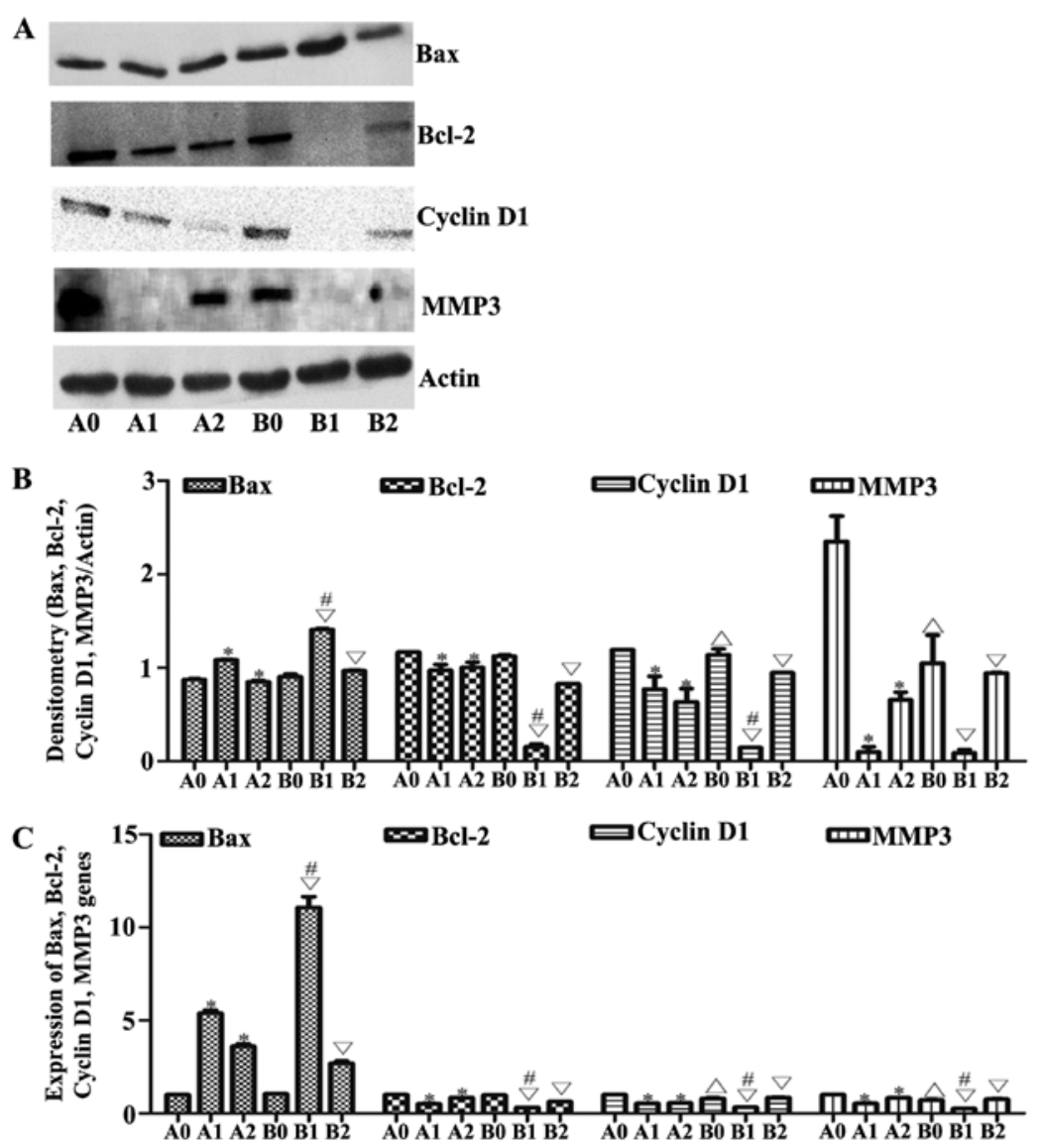

Figure 6. Changes of downstream mRNAs. (A and B) Bax, Bcl-2, cyclin D1, MMP3 expression levels were determined by western blotting; $\beta$-actin served as a protein loading control. (C) The expressions of Bax, Bcl-2, cyclin D1 and MMP3 mRNAs were measured by qRT-PCR. Results shown are representative of at least three independent experiments. ${ }^{*} \mathrm{P}<0.05$ vs. control. ${ }^{*} \mathrm{P}<0.01$, HepG2- $\beta$-catenin $+(S) \mathrm{Rh} 2$, shRNA- $\beta$-catenin-HepG $2+(S) \mathrm{Rh} 2+\mathrm{BIO}$ vs. HepG2- $\beta$-catenin group; ${ }^{\Delta} \mathrm{p}<0.0$, HepG2 vs. HepG2- $\beta$-catenin; ${ }^{\nabla} \mathrm{p}<0.01, \mathrm{HepG} 2+(S) \mathrm{Rh} 2, \mathrm{HepG} 2+(S) \mathrm{Rh} 2+\mathrm{BIO}$ vs. HepG2; ${ }^{\mathrm{p}}<<0.01, \mathrm{HepG} 2+(S) \mathrm{Rh} 2$ vs. HepG2- $\beta$-catenin $+(S) \mathrm{Rh} 2$. A0, HepG2- $\beta$-catenin; A1, HepG2- $\beta$-catenin + $(S)$ Rh2; A2, HepG2- $\beta$-catenin + $(S)$ Rh2 + BIO; B0, HepG2; B1, HepG2 + $(S)$ Rh2; B2, HepG2 + $(S)$ Rh2 + BIO; (S)Rh2, 20(S)-ginsenoside Rh2.

that of the HepG2 + $(S)$ Rh2 group, and the difference between them was statistically significant $(\mathrm{p}<0.01)$. The results of FCM showed that overexpression of $\beta$-catenin could decrease the pharmacological effect on apoptosis of HepG2 (Fig. 3B).

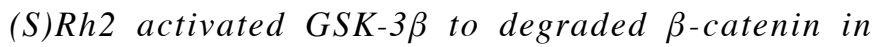
HepG2- $\beta$-catenin and Hep 2 cells. The stability of $\beta$-catenin depends on GSK-3 $\beta$. ELISA kit was used to analyze the activity of GSK-3 $\beta$, and the results indicated that the activity of GSK-3 $\beta$ gradually increased when HepG 2 cells were induced by $(S) \mathrm{Rh} 2$ for $12,24,48$ and $72 \mathrm{~h}$, reaching the peak in $48 \mathrm{~h}$ and then decreased (Fig. 4A). Next, GSK-3 $\beta$ inhibitor BIO was used to verify whether $(S)$ Rh2 activated GSK-3 $\beta$. The activity of GSK-3 $\beta$ in HepG $2-\beta$-catenin $+(S)$ Rh 2 and HepG $2+(S)$ Rh 2 groups reduced after BIO was added (Fig. 4B). These results suggested that $(S) \mathrm{Rh} 2$ activates the activity of GSK-3 $\beta$. Furthermore, GSK-3 $\beta$ and $\beta$-catenin mRNA and protein expression treated with $(S) \mathrm{Rh} 2$ or $(S) \mathrm{Rh} 2+\mathrm{BIO}$ was analyzed. The PCR and western blotting results showed that the expression of GSK-3 $\beta$ mRNA and proteins increased in HepG 2 and HepG2- $\beta$-catenin cells induced by $(S)$ Rh2, but the expression of GSK-3 $\beta$ did not show significant difference between HepG2- $\beta$-catenin $+(S) \mathrm{Rh} 2$ and HepG $2+(S) \mathrm{Rh} 2$ groups (Fig. 5A-C). In order to further validate that upregulated GSK-3 $\beta$ would adjust to the effect of downstream
mRNA and protein, PCR and western blotting were used to determine the expression of $\beta$-catenin mRNA and protein. The PCR and western blotting results showed that the expression of $\beta$-catenin mRNA and proteins was downregulated in HepG2 and HepG2- $\beta$-catenin cells induced by $(S)$ Rh2. So we presumed that ginsenoside $(S) \mathrm{Rh} 2$ degraded $\beta$-catenin through activating GSK-3 $\beta$.

Changes of downstream $m R N A s$. To check the relationship between $\beta$-catenin and TCF4, ChIP assay kit was used. The expression of downstream genes, including Bax, Bcl-2, cyclin D1 and MMP3, was measured by PCR. The ChIP results showed that the expression of Bax mRNA increased, while the cyclin D1, Bcl-2 and MMP3 mRNA expressions were downregulated in HepG2 and HepG2- $\beta$-catenin cells induced by $(S) \mathrm{Rh} 2$. Compared with HepG2- $\beta$-catenin $+(S)$ Rh2 group, the expression of Bax mRNA in HepG $2+(S)$ Rh 2 group increased significantly, and the expressions of Bcl-2, cyclin D1 and MMP3 mRNA were also significantly low, between which the difference was statistically significant (Fig. 5D). The PCR and western blotting results showed that the expression of Bax mRNA and proteins increased, while the expression of cyclin D1, Bcl-2 and MMP3 mRNA and proteins were downregulated in HepG2 and HepG2- $\beta$-catenin cells induced by (S)Rh2 (Fig. 6A-C). 

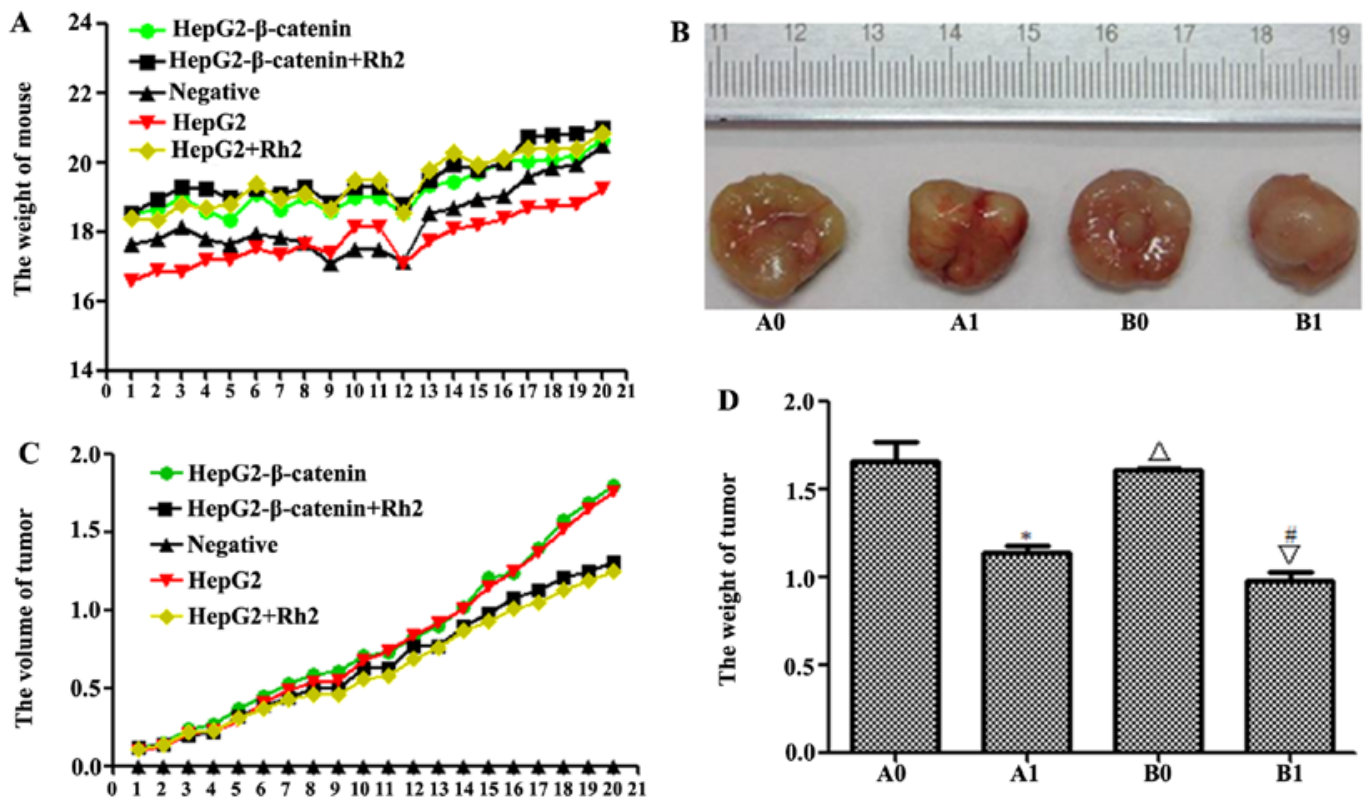

Figure 7. Effect of $(S) \mathrm{Rh} 2$ on the growth of established HepG2- $\beta$-catenin and HepG2 tumors in nude mice. Mice were randomized into five groups. Each mouse was inoculated subcutaneously in the left flank with $5 \times 10^{7} \mathrm{HepG} 2-\beta$-catenin and HepG2 cells or normal saline in a total volume of $0.1 \mathrm{ml}$. $(S) \mathrm{Rh} 2$ was given to the tumor-bearing mice. There was no statistically significant difference in changes in the body weight of mice between treatment groups, and no signs of other toxic effects were observed during the period. (A) Mean weight of mice for each group is indicated. (B) Each bar represents the mean \pm SEM of tumor volume of five animals per group. (C) Mean diameter of tumor for each group is indicated. (D) Mean weight of tumor for each group is indicated. Results are represented as the mean \pm SEM of five animals per group. ${ }^{*} \mathrm{P}<0.01$, HepG2- $\beta$-catenin $+(S) \mathrm{Rh} 2$ vs. HepG2- $\beta$-catenin group; ${ }^{\Delta} \mathrm{p}<0.01$, HepG2 vs. HepG2- $\beta$-catenin; ${ }^{\nabla}$ p $<0.01$, HepG2 $+(S)$ Rh2 vs. HepG2; ${ }^{\#}$ p $<0.01$, HepG2 + $(S)$ Rh2 vs. HepG2- $\beta$-catenin $+(S)$ Rh2. A0, HepG2- $\beta$-catenin; A1,

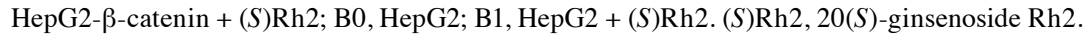

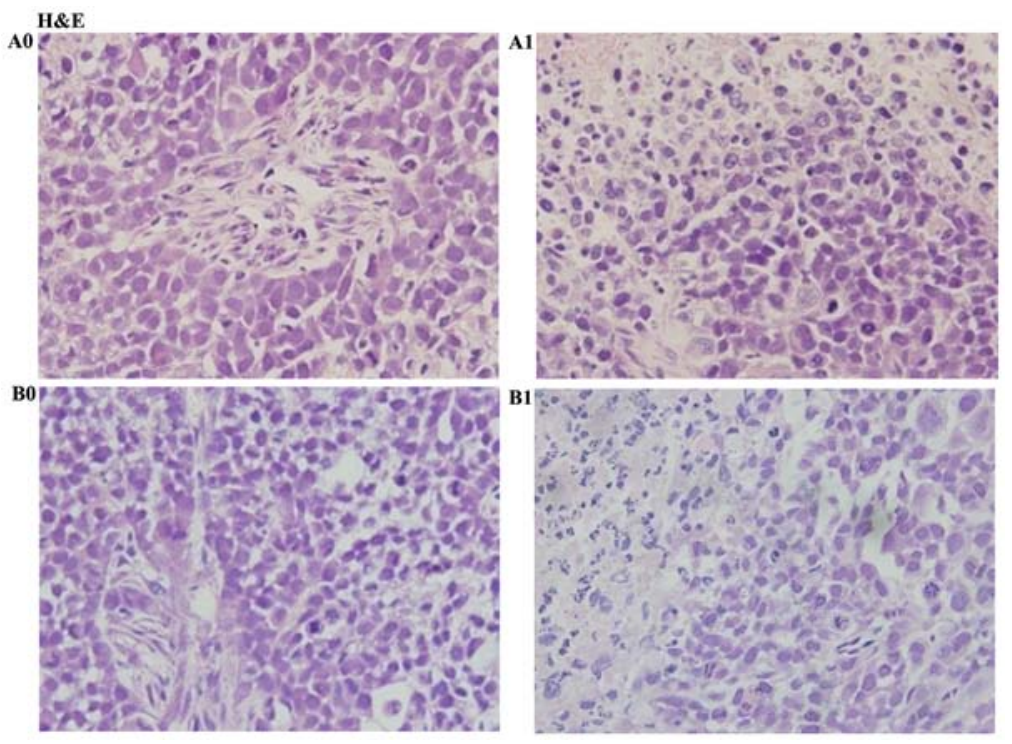

Figure 8. H\&E staining. H\&E was used to observe the cell morphology. A0, HepG2- $\beta$-catenin; A1, HepG2- $\beta$-catenin $+(S)$ Rh2; B0, HepG2; B1, HepG2 + $(S)$ Rh2. (S)Rh2, 20(S)-ginsenoside Rh2.

Effect of (S)Rh2 on nude mouse xenograft model. To evaluate the effect of $(S) \mathrm{Rh} 2$ on tumor growth, nude mice inoculated with HepG2- $\beta$-catenin and HepG2 cells were treated with $(S) \mathrm{Rh} 2(20 \mathrm{mg} / \mathrm{kg}) .(S) \mathrm{Rh} 2$ was administered every day for 20 days consecutively. The mice grew well, and the weight of the mice increased every day. The weight of tumor in HepG2- $\beta$-catenin group $(1.7 \pm 0.19 \mathrm{~g})$ was greater than that in the HepG2 group $(1.6 \pm 0.16 \mathrm{~g})$; the weight of tumor in HepG2- $\beta$-catenin $+(S) \mathrm{Rh} 2$ group $(1.10 \pm 0.12 \mathrm{~g})$ was greater than that in the HepG2 $+(S) \mathrm{Rh} 2$ group $(1.0 \pm 0.13 \mathrm{~g})$, and the difference between them was statistically significant $(p<0.01)$. The alterations in tumor volume as well as diameter changed similarly to weight (Fig. 7A-D). Tumor sections were paraffin-embedded and H\&E stain was used to observe the cell morphology. The results showed nucleus atypia and accounted for a large proportion of the cells in HepG2 and HepG2- $\beta$-catenin cells. But atypia in the nucleus in HepG2- $\beta$-catenin group was more obvious. Condensation in nuclei and many broken 

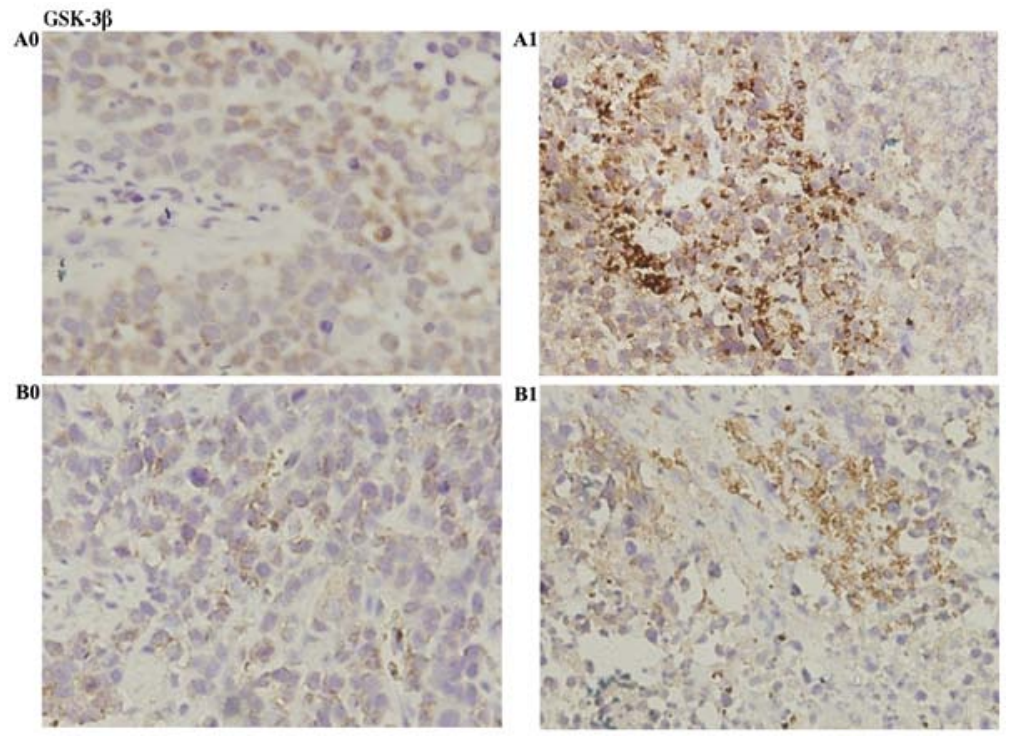

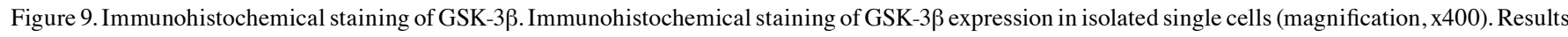
shown are representative of at least three independent experiments. A0, HepG2- $\beta$-catenin; A1, HepG2- $\beta$-catenin $+(S) \mathrm{Rh} 2 ; \mathrm{B} 0, \mathrm{HepG} ; \mathrm{B} 1, \mathrm{HepG} 2+(S) \mathrm{Rh} 2$. GSK-3 $\beta$, glycogen synthase kinase-3 $\beta ;(S)$ Rh2, 20(S)-ginsenoside Rh2.
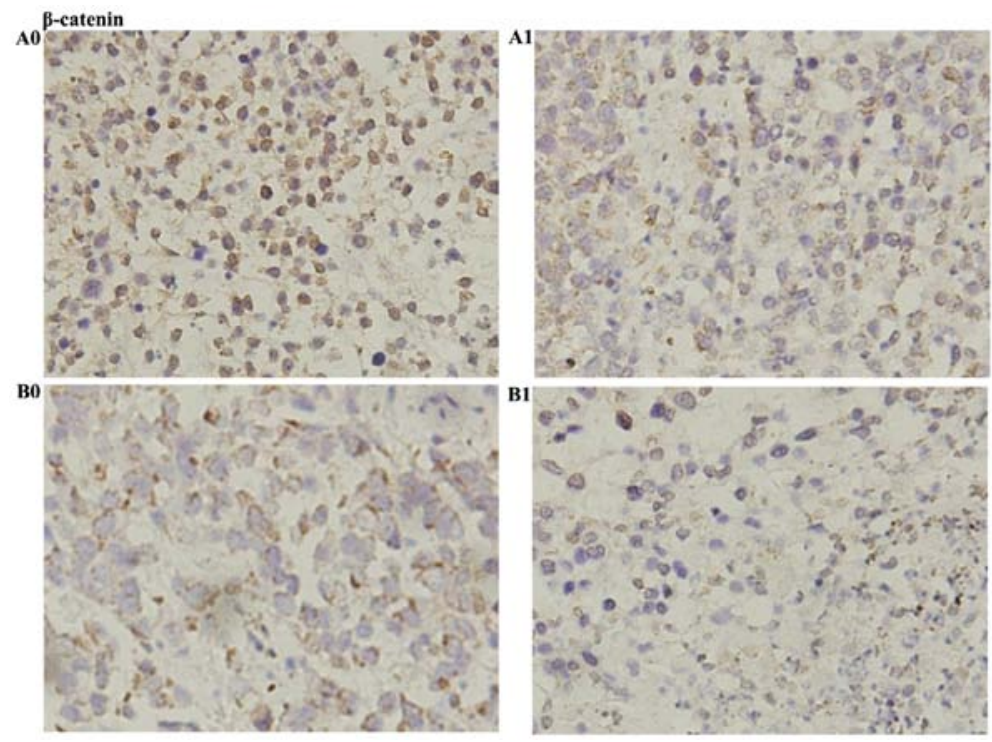

Figure 10. Immunohistochemical staining of $\beta$-catenin. Immunohistochemical staining of $\beta$-catenin expression in isolated single cells (magnification, $\mathrm{x} 400)$. Results shown are representative of at least three independent experiments. A0, HepG2- $\beta$-catenin; A1, HepG2- $\beta$-catenin $+(S) \mathrm{Rh} 2$; B0, HepG2; B1, HepG2 + $(S) \mathrm{Rh} 2 .(S) \mathrm{Rh} 2,20(S)$-ginsenoside Rh2.

cells were observed in HepG2- $\beta$-catenin $+(S) \mathrm{Rh} 2$ and HepG2 $+(S) \mathrm{Rh} 2$ groups. However, condensation in nuclei and broken cells in HepG2 $+(S) \mathrm{Rh} 2$ group was greater (Fig. 8). Immunohistochemical results indicated that the expression of GSK- $3 \beta$ increased, and $\beta$-catenin and MMP 3 expressions decreased in HepG2- $\beta$-catenin $+(S) \mathrm{Rh} 2$ group, compared with HepG2- $\beta$-catenin group. The expression of $\beta$-catenin and MMP3 in HepG2 $+(S)$ Rh2 group was weaker than that of the HepG2- $\beta$-catenin + $(S)$ Rh2 group, while GSK-3 $\beta$ was not significantly different (Figs. 9-11). ELISA kit was used to analyze the activity of GSK-3 $\beta$ and it was found that the activity of GSK-3 $\beta$ increased in HepG $2+(S)$ Rh2 and HepG2- $\beta$-catenin $+(S)$ Rh 2 groups (Fig. $12 \mathrm{~A})$. The PCR and western blotting results showed that the expression of
GSK-3 $\beta$ mRNA and protein increased, while the expression of $\beta$-catenin mRNA and protein was downregulated in HepG2 and HepG2- $\beta$-catenin cells induced by $(S) \mathrm{Rh} 2$. Compared with the HepG2- $\beta$-catenin $+(S) \mathrm{Rh} 2$ group, the expression of $\beta$-catenin protein in HepG2 $+(S) \mathrm{Rh} 2$ group was also significantly low, and the difference between them was statistically significant. In vivo experiment, the expression of Bax gene increased, while the expression of cyclin D1, Bcl-2 and MMP3 genes was downregulated in HepG2 and HepG2- $\beta$-catenin cells induced by $(S) \mathrm{Rh} 2$. Compared with HepG2- $\beta$-catenin $+(S) \mathrm{Rh} 2$ group, the expression of Bax gene in $\mathrm{HepG} 2+(S) \mathrm{Rh} 2$ group increased significantly, and the expression of Bcl-2, cyclin D1 and MMP3 mRNA was also significantly low, and the difference between them was statistically significant $(\mathrm{p}<0.01)$. These results 


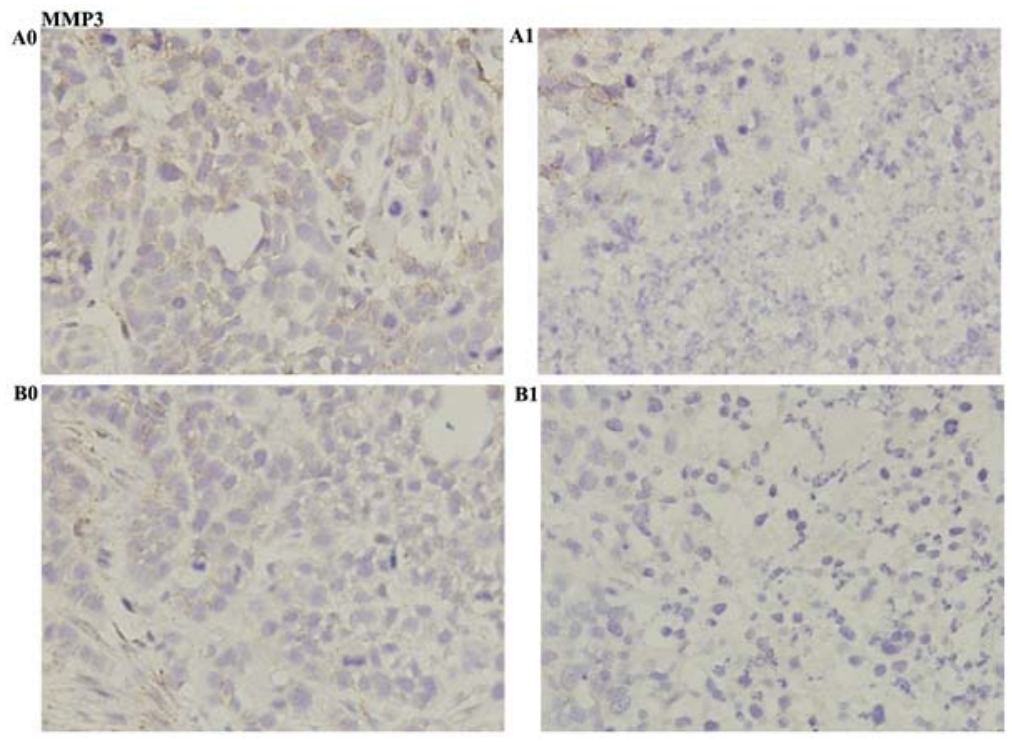

Figure 11. Immunohistochemical staining of MMP3. Immunohistochemical staining of MMP3 expression in isolated single cells (magnification, $\mathrm{x} 400)$. Results shown are representative of at least three independent experiments. A0, HepG2- $\beta$-catenin; A1, HepG2- $\beta$-catenin $+(S)$ Rh2; B0, HepG2; B1, HepG2 + $(S)$ Rh2 . $(S) \mathrm{Rh} 2,20(S)$-ginsenoside $\mathrm{Rh} 2$.
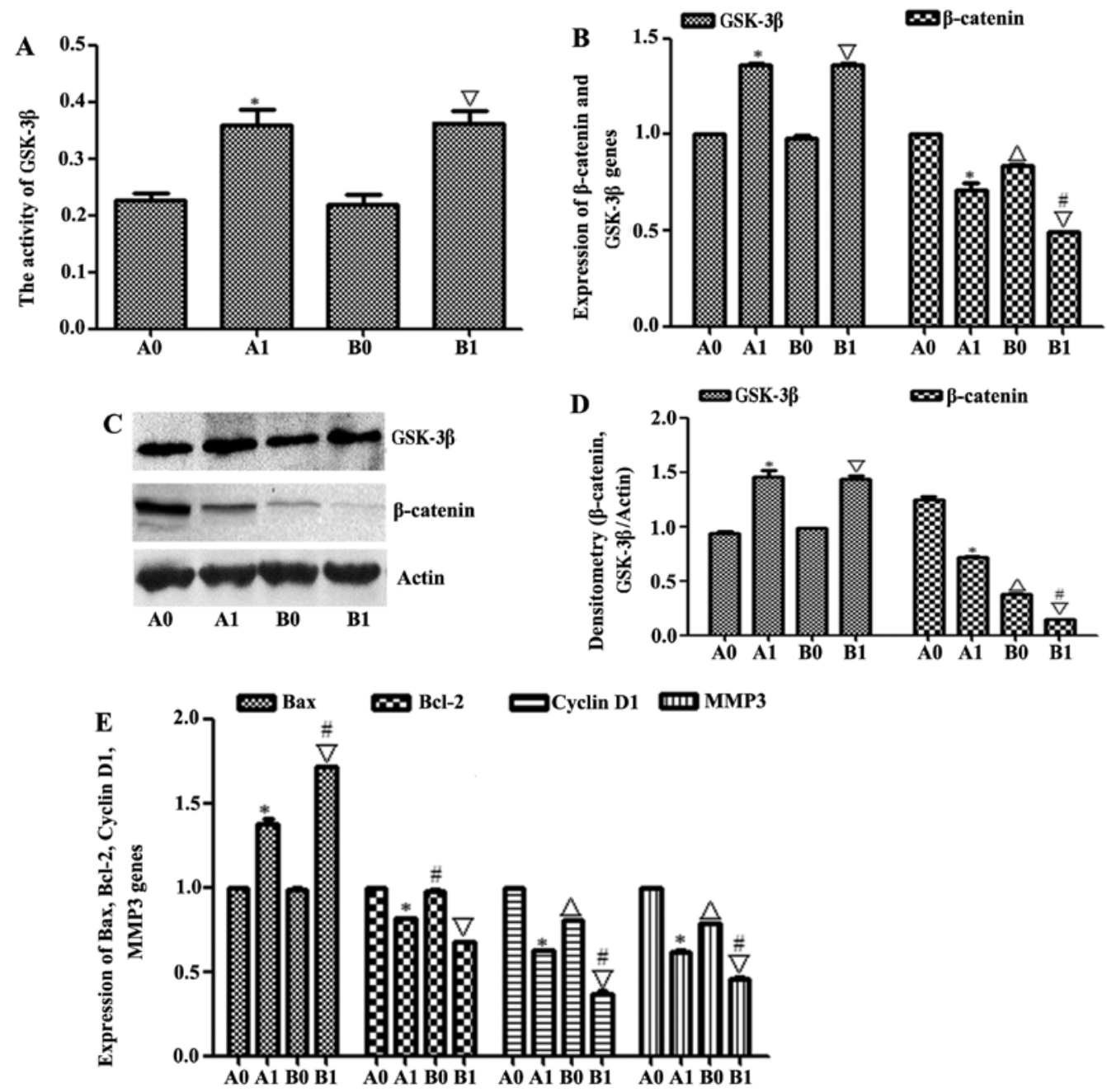

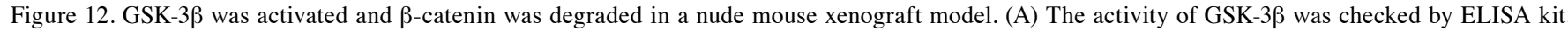
(B and C) GSK-3 $\beta$ and $\beta$-catenin expression levels were determined by western blotting; $\beta$-actin served as a protein loading control. (D) The expression of GSK-3 $\beta$ and $\beta$-catenin mRNAs was measured by qRT-PCR. (E) The expressions of Bax, Bcl-2, cyclin D1 and MMP3 mRNAs was measured by qRT-PCR. Results shown are representative of at least three independent experiments. ${ }^{*} \mathrm{P}<0.01$, HepG2- $\beta$-catenin $+(S) \mathrm{Rh} 2$ vs. HepG2- $\beta$-catenin group; ${ }^{\circ} \mathrm{p}<0.01$, HepG2 vs. HepG2- $\beta$-catenin; ${ }^{\nabla} \mathrm{p}<0.01, \mathrm{HepG} 2+(S) \mathrm{Rh} 2$ vs. HepG2; ${ }^{\#} \mathrm{p}<0.01, \mathrm{HepG} 2+(S)$ Rh2 vs. HepG2- $\beta$-catenin $+(S)$ Rh2. A0, HepG2- $\beta$-catenin; A1,

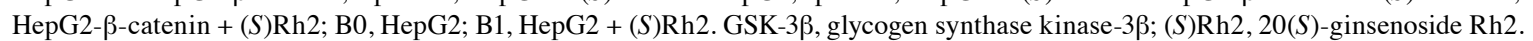


supported that activating GSK-3 $\beta$ in vivo could contribute to inhibiting the tumor growth in HepG2- $\beta$-catenin $+(S) \mathrm{Rh} 2$ and HepG2 $+(S)$ Rh2 groups.

\section{Discussion}

Panax ginseng has been used for treatment of disease in Chinese Traditional Medicine for thousands of years, and it has also been employed in recent years for adjuvant therapy in various types of cancers $(25)$. It has been found that $(S) \mathrm{Rh} 2$ could help induce apoptosis in pancreatic cancer, hepatoma and A549 lung cancer cells (11). It was found in this experiment that the proliferation of HepG2 cells at various concentrations of $(S) \mathrm{Rh} 2$ were inhibited to some degree, compared with the control group, and the difference between them is statistically significant. The inhibition effect of $(S) \mathrm{Rh} 2$ on HepG2 liver cancer cell growth was dose- and time-dependent, and the $\mathrm{IC}_{50}$ of $(S) \mathrm{Rh} 2$ exposure on HepG2 cells for 48 and $72 \mathrm{~h}$ was 100 and $58.12 \mu \mathrm{mol} / 1$, respectively (Fig. 2A). It has been found through other studies in the laboratory that the effect of TSPG and $(S)$ Rh2 inhibiting cell proliferation and inducing apoptosis in KG1 $\alpha$ and $\beta$-catenin protein significantly reduced in the nucleus, and expression in the nucleus transferred to the cell membrane. Clinical studies showed that overexpression of $\beta$-catenin could resist to chemotherapy or radiotherapy and lead to poor prognosis (18). Lentivirus carrying $\beta$-catenin was used to infect HepG2 cells so as to establish HepG2- $\beta$-catenin cells. $(S) \mathrm{Rh} 2$ inhibited HepG2- $\beta$-catenin cell proliferation dose- and time-dependently, and the $\mathrm{IC}_{50}$ of $(S) \mathrm{Rh} 2$ exposure on HepG2- $\beta$-catenin cells for 48 and $72 \mathrm{~h}$ are 129.2 and $83.33 \mu \mathrm{mol} / 1$ (Fig. 2B), respectively. The results showed that overexpression of $\beta$-catenin decreased the pharmacological effects of ginsenoside $(S) \mathrm{Rh} 2$ on hepatoma HepG2 cells.

According to previous reports, the constitutive activation of $\mathrm{Wnt} / \beta$-catenin signaling would promote cell proliferation and tumorigenesis in tissues as well as in the colon and the pancreas (21). In order to explore the effect of $(S) \mathrm{Rh} 2$ and overexpression of $\beta$-catenin on cell cycle and apoptosis of HepG2 hepatoma cells, FCM was used to detect the cycle proportion in each group of cells, including HepG2, HepG2 $+(S) \mathrm{Rh} 2$, HepG2- $\beta$-catenin and HepG2- $\beta$-catenin $+(S) \mathrm{Rh} 2$ group. Compared with HepG2 cells, the proportion of HepG2- $\beta$-catenin cells in $\mathrm{G} 0 / \mathrm{G} 1$ phase $(52.86 \pm 1.46 \%)$ was significantly lower than that in HepG2 group $(61.02 \pm 1.48 \%)$. This result indicated that overexpression of $\beta$-catenin could reduce the cycle proportion in G0/G1 phase, which could accelerate cell proliferation (Fig. 3A). It was found that cycle percentage of G0/G1 phase was increased in HepG2 and HepG2- $\beta$-catenin cells induced by $(S) \mathrm{Rh} 2$. The result showed that the anticancer effect of $(S) \mathrm{Rh} 2$ was achieved by arresting the cell cycle in G0/G1 phase (Fig. 3A). Cyclin D1 played a critical role in controlling the proliferation of malignant tumors, which could transit G1 to $S$ phase (26), detected by PCR, ChIP and western blotting. The expression of cyclin D1 mRNA and protein reduced in HepG2 and HepG2- $\beta$-catenin cells induced by $(S) \mathrm{Rh} 2$ (Fig. 6A-C). Downregulating the cyclin D1 expression could suppress uncontrolled proliferation of tumor cells. The expressions of cyclin D1 mRNA and protein levels in HepG2 $+(S)$ Rh2 group were significantly lower than that in HepG2- $\beta$-catenin $+(S) \mathrm{Rh} 2$ group, and the difference between them was statistically significant $(p<0.01)$. The result showed that overexpression of $\beta$-catenin might weaken the effect of $(S) \mathrm{Rh} 2$ downregulating the expression of cyclin D1 mRNA and protein levels. FCM was used to detect apoptosis of cells. The experimental results indicated that the rate of cell apoptosis increased in HepG2 $+(S) \mathrm{Rh} 2$ and HepG2- $\beta$-catenin $+(S) \mathrm{Rh} 2$ groups, among which the rate of cell apoptosis in HepG2- $\beta$-catenin $+(S) \mathrm{Rh} 2$ was lower than that in $\mathrm{HepG} 2+(S) \mathrm{Rh} 2$ (Fig. 3B) group. The above results indicated that overexpression of $\beta$-catenins might weaken the effect of survival inhibition and reduce the rate of apoptosis inhibition on HepG2 liver cancer cells. From analysis of 80 cases, it was found that the expression level of GSK-3 $\beta$ protein in HCC was significantly lower than that of normal liver tissue and cancerous tissue, and indicated a poor prognosis. GSK-3 $\beta$ expression was also correlated with vascular invasion, TNM classification. Therefore it could be involved in the process of HCC metastasis (19). GSK-3 $\beta$ has carcinogenic potential and is also a favorable target for anticancer therapy (20). An ELISA assay kit was used to detect the activity of GSK-3 $\beta$ in HepG2 and HepG2- $\beta$-catenin cells, and GSK-3 $\beta$ was able to be activated by $(S)$ Rh2 in a time-dependent manner (Fig. 4A). Next, GSK-3 $\beta$ inhibitor BIO was used to verify whether $(S) \mathrm{Rh} 2$ activated GSK-3 $\beta$. The activity of GSK-3 $\beta$ was decreased both in HepG2 and HepG2- $\beta$-catenin cells induced by $(S) \mathrm{Rh} 2$ and BIO, significantly lower than HepG2 and HepG2- $\beta$-catenin cell group, which proved that $(S)$ Rh2 activated GSK-3 $\beta$ and the pharmacologic action of $(S) \mathrm{Rh} 2$ could be antagonized by BIO (Fig. 4B). PCR and western blotting were used to detect the expression of GSK- $3 \beta$ mRNA and protein in HepG2 and HepG2- $\beta$-catenin cells induced by $(S) \mathrm{Rh} 2$ for $48 \mathrm{~h}$. The expression of GSK-3 $\beta$ mRNA and protein increased. These results suggested that $(S) \mathrm{Rh} 2$ could activate GSK-3 $\beta$ and enhance the expression of GSK-3 $\beta$ (Fig. 5A and B).

$\beta$-catenin both in cancer and normal tissues is an important molecule, whose stability depends on the degradation complex, including Axin, APC and GSK-3 $\beta$, and is regulated mainly by GSK-3 $\beta$ in the cells $(21,27,28)$. The activity of GSK-3 $\beta$ increased in HepG 2 and HepG2- $\beta$-catenin cells induced by $(S) \mathrm{Rh} 2$ for $48 \mathrm{~h}$. The stability of $\beta$-catenin depended on the regulation of GSK-3 $\beta$. PCR and western blotting were used to detect the expression of $\beta$-catenin mRNA and protein in HepG2. As a result the expression of $\beta$-catenin mRNA and protein in HepG2 $+(S)$ Rh2 group significantly decreased, in contrast to HepG2. HepG2- $\beta$-catenin cells were also detected. The results showed that $\beta$-catenin mRNA and protein in HepG2- $\beta$-catenin $+(S) \mathrm{Rh} 2$ group were lower than that in HepG2- $\beta$-catenin cells, and the $\beta$-catenin mRNA and protein reducing rate was lower than that in HepG2 $+(S)$ Rh2 group (Fig. 5A and B). The results showed that overexpression of $\beta$-catenin could weaken the effect of $(S) \mathrm{Rh} 2$ degrading $\beta$-catenin. Furthermore, it was confirmed that the GSK-3 $\beta$ was increased by ginsenoside $(S) \mathrm{Rh} 2$ so as to degrade $\beta$-catenin.

In Wnt stimulation, GSK-3 $\beta$ transferred to the cell membrane and bound with dishevelled and LRP-5 receptor, thereby preventing the GSK- $3 \beta$ to phosphorylate $\beta$-catenin $(20,27)$. As a result, the $\beta$-catenin escaped the proteasome to degradation, which accumulated in the cytoplasm and then shifted to the nucleus (28). When chromatin was in a loose state, $\beta$-catenin shifting into the nucleus could 
combine with TCF and HDACs/Groucho complex. After combination, $\mathrm{N}$ - and $\mathrm{C}$-terminus of $\beta$-catenin exposure, $\mathrm{HAT}$ protein $\mathrm{CBP}$ and p300 interacted with $\beta$-catenin $\mathrm{R} 10-\mathrm{C}$ area. Next, transcription factors, transcription complexes and RNA polymerase were recruited on $\beta$-catenin platform to activate the downstream genes, including Bax, Bcl-2, cyclin D1 and MMP3 (22,23). PCR was used to detect the changes of Bax, Bcl-2, cyclin D1 and MMP3 mRNA in HepG2 cells induced by $(S) \mathrm{Rh} 2$. The results showed that the expression of Bax mRNA in HepG $2+(S)$ Rh2 group increased, while the expressions of Bcl-2 and MMP3 mRNA downregulated, in contrast to the HepG2 group. Previous experimental results showed that $\beta$-catenin expression was significantly decreased in HepG 2 cells induced by $(S) \mathrm{Rh} 2$ (Fig. 6C). In order to further explore the decreasing effect of $\beta$-catenin in cell nuclear on downstream mRNAs, ChIP method was used to detect downstream mRNAs. The results showed that the expression of Bax mRNA in HepG2 $+(S) \mathrm{Rh} 2$ group increased, while the expression of cyclin D1, Bcl-2 and MMP3 mRNA downregulated, compared with HepG2 group (Fig. 5C). It was important that the western blotting results agreed with ChIP results (Fig. 6A and B). The Bax, Bcl-2, cyclin D1, MMP3 mRNA and protein in HepG2- $\beta$-catenin $+(S)$ Rh2 and HepG2 + $(S) \mathrm{Rh} 2$ groups were also examined. It was found that the degree of Bax mRNA and protein was increased and the extent of Bcl-2, cyclin D1, MMP3 mRNA and protein was reduced in HepG2- $\beta$-catenin $+(S) \mathrm{Rh} 2$ group, which was weaker than that of HepG $2+(S) \mathrm{Rh} 2$ group, and the difference between them was statistically significant $(\mathrm{p}<0.01)$ (Fig. 6A-C). The results showed that $(S) \mathrm{Rh} 2$ activated GSK-3 $\beta$ to degrade $\beta$-catenin, reduced the number of $\beta$-catenin shifting into the nucleus, thereby inhibiting the expression of the cycle, proliferation and migration-related protein, then promoted the expression of apoptosis-related proteins, and ultimately inhibited the proliferation of HepG2 cells and promoted their apoptosis. Re-expression of $\beta$-catenin could weaken apoptosis in HepG2 cells induced by $(S) \mathrm{Rh} 2$, which was also consistent with the results of apoptosis by FCM.

In vivo, $(S) \mathrm{Rh} 2$ was administered for mice by oral gavage with $20 \mathrm{mg} / \mathrm{kg}$, which equates to $1.6 \mathrm{mg} / \mathrm{kg}$ for humans. In addition, the dosage used in this study was based on several reports by other researchers. The weight of tumor in HepG2- $\beta$-catenin and HepG2 groups induced by $(S) \mathrm{Rh} 2$ was significantly reduced. Earlier experiments illustrated that the overexpression of $\beta$-catenin accelerated the proliferation of HepG2 cells in vitro. In vivo experiments, it was found that the weight of tumor in HepG2- $\beta$-catenin group $(1.7 \pm 0.19 \mathrm{~g})$ was greater than that of HepG2 group (1.6 $\pm 0.16 \mathrm{~g})$, and the difference between them was statistically significant $(\mathrm{p}<0.01)$. The results indicated that overexpression of $\beta$-catenin increased the weight of tumor. It was also observed that the weight of tumor in HepG2- $\beta$-catenin $+(S) \mathrm{Rh} 2$ group $(1.7 \pm 0.19 \mathrm{~g})$ was greater than that of HepG2 $+(S) \mathrm{Rh} 2$ group $(1.0 \pm 0.13 \mathrm{~g})$, and the difference between them was statistically significant $(\mathrm{p}<0.01)$. The results elucidated that overexpression of $\beta$-catenin could weaken the pharmacological effect of $(S)$ Rh2 on HepG2 cells (Fig. 7A-D). Tumor sections were paraffin-embedded. H\&E staining was used to observe the morphology of cells in the tumor tissue. It showed nucleus atypia and accounted for a large proportion of the whole cells in HepG 2 and HepG2- $\beta$-catenin cells. But the nuclear atypia in HepG2- $\beta$-catenin group was more obvious. Condensation in nuclei and abundant broken cells were observed in HepG2- $\beta$-catenin $+(S) \mathrm{Rh} 2$ and HepG $2+(S) \mathrm{Rh} 2$ groups. However, condensation in nuclei and broken cells in HepG $2+(S)$ Rh2 group was more significant (Fig. 8). The results indicated that overexpression of $\beta$-catenin could cause abnormal proliferation of the tumor, and weaken the pharmacological effect of $(S) \mathrm{Rh} 2$ on HepG2 cells.

In vitro, it was found that anticancer effect of $(S) \mathrm{Rh} 2$ on HepG2 cells was achieved by the GSK-3 $\beta / \beta$-catenin pathway. In order to further detect the role of the signal pathway in vivo, immunohistochemistry was used to detect the distribution of GSK-3 $\beta$. Brown granules of GSK-3 $\beta$ in HepG2- $\beta$-catenin and HepG2 tumor tissues mainly located in the cytoplasm. When they were induced by $(S) \mathrm{Rh} 2$, the number of brown granules increased significantly (Fig. 9). ELISA results also showed that the activity of GSK-3 $\beta$ significantly increased in HepG $2-\beta$-catenin and HepG2 tumor tissues induced by $(S) \mathrm{Rh} 2$. The results showed that $(S) \mathrm{Rh} 2$ also activated GSK-3 $\beta$ in tumor tissues (Fig. 12A). In vitro, it was found that stability of $\beta$-catenin depended on the regulation of GSK-3 $\beta$. Immunohistochemistry was used to detect the position of $\beta$-catenin, and it was found that brown granules of $\beta$-catenin stored in cytoplasm and nucleus in HepG2- $\beta$-catenin and HepG 2 tumor tissues, but brown granules of $\beta$-catenin in the HepG2- $\beta$-catenin group was more abundant than that in HepG2 group. When they were induced by $(S) \mathrm{Rh} 2$, the volume of $\beta$-catenin brown granules in the cytoplasm and the nucleus was reduced, which further confirmed that $(S) \mathrm{Rh} 2$ degraded $\beta$-catenin through activating GSK-3 $\beta$ in vivo (Fig. 11).

The effect of ginsenoside $(S) \mathrm{Rh} 2$ on cancer was evident, but its ability to inhibit tumor migration had not been previously elucidated. $\beta$-catenin is also an adhesion molecule, but there has been only a handful of studies reporting its role in metastasis. MMP3 is a significant proteolytic enzyme to degrade the extracellular matrix, which degraded the main component of the extracellular matrix and basement membrane collagen IV to participate in the process of tumor invasion and metastasis, therefore it contributed to metastasis (29-31). In order to investigate this, western blotting and immunohistochemical staining was used to check the $\beta$-catenin and MMP3. The results indicated that $(S) \mathrm{Rh} 2$ reduced the expression levels of $\beta$-catenin, MMP3 mRNA and protein (Fig. 12B-E). The results also suggested that $(S)$ Rh2 could inhibit tumor metastasis.

In general, $(S) \mathrm{Rh} 2$ suppressed proliferation, promoted apoptosis and inhibited metastasis of HepG2, decreased the weight of tumors by downregulating $\beta$-catenin through activating GSK-3 $\beta$, and the pharmacological effect of $(S) \mathrm{Rh} 2$ on HepG 2 cells might be weakened by overexpression of $\beta$-catenin.

\section{Acknowledgements}

We would like to express our great gratitude to the National Natural Science Foundation of China for grant support for this research (nos. KJ130312 and 81171929). We also wish to thank the College of Life Sciences for its technical support. 


\section{References}

1. Tsai WL, Lai KH, Liang HL, Hsu PI, Chan HH, Chen WC, Yu HC, Tsay FW, Wang HM, Tsai HC, et al: Hepatic arterial infusion chemotherapy for patients with huge unresectable hepatocellular carcinoma. PLoS One 9: e92784, 2014.

2. Page AJ, Cosgrove DC, Philosophe B and Pawlik TM: Hepatocellular carcinoma: Diagnosis, management, and prognosis. Surg Oncol Clin N Am 23: 289-311, 2014.

3. Scaggiante B, Kazemi M, Pozzato G, Dapas B, Farra R, Grassi M, Zanconati $\mathrm{F}$ and Grassi G: Novel hepatocellular carcinoma molecules with prognostic and therapeutic potentials. World $\mathbf{J}$ Gastroenterol 20: 1268-1288, 2014.

4. Tanase A-M, Dumitrascu T, Dima S, Grigorie R, Marchio A, Pineau $\mathrm{P}$ and Popescu I: Influence of hepatitis viruses on clinicopathological profiles and long-term outcome in patients undergoing surgery for hepatocellular carcinoma. Hepatobiliary Pancreat Dis Int 13: 162-172, 2014.

5. Ji Z, Wang T, Shao Z, Huang D, Wang A, Guo Z, Long Y, Zhang L, Su H, Zhang Q, et al: A population-based study examining hepatitis $B$ virus infection and immunization rates in Northwest China. PLoS One 9: e97474, 2014.

6. Xu L-B, Wang J, Liu C, Pang HW, Chen YJ, Ou QJ and Chen JS: Staging systems for predicting survival of patients with hepatocellular carcinoma after surgery. World J Gastroenterol 16: 5257-5262, 2010.

7. Osaki A, Suda T, Kamimura K, Tsuchiya A, Tamura Y, Takamura M, Igarashi M, Kawai H, Yamagiwa S and Aoyagi Y: A safe and effective dose of cisplatin in hepatic arterial infusion chemotherapy for hepatocellular carcinoma. Cancer Med 2: 86-98, 2013.

8. Ker CG, Chen JS, Kuo KK, Chuang SC, Wang SJ, Chang WC, Lee KT, Chen HY and Juan CC: Liver surgery for hepatocellular carcinoma: Laparoscopic versus open approach. Int J Hepatol 2011: 596792, 2011.

9. Miyahara K, Nouso K and Yamamoto K: Chemotherapy for advanced hepatocellular carcinoma in the sorafenib age. World J Gastroenterol 20: 4151-4159, 2014.

10. Song SB, Tung NH, Quang TH, Ngan NT, Kim KE and Kim YH: Inhibition of TNF- $\alpha$-mediated NF- $\kappa B$ transcriptional activity in HepG 2 cells by dammarane-type saponins from Panax ginseng leaves. J Ginseng Res 36: 146-152, 2012.

11. Guo XX, Guo Q, Li Y, Lee SK, Wei XN and Jin YH: Ginsenoside Rh2 induces human hepatoma cell apoptosisvia bax/bak triggered cytochrome $\mathrm{C}$ release and caspase-9/caspase- 8 activation. Int J Mol Sci 13: 15523-15535, 2012.

12. Wang Z, Zheng Q, Liu K, Li G and Zheng R: Ginsenoside Rh(2) enhances antitumour activity and decreases genotoxic effect of cyclophosphamide. Basic Clin Pharmacol Toxicol 98: 411-415, 2006.

13. Ho YL, Li KC, Chao W, Chang YS and Huang GJ: Korean red ginseng suppresses metastasis of human hepatoma SK-Hep1 cells by inhibiting matrix metalloproteinase-2/-9 and urokinase plasminogen activator. Evid Based Complement Alternat Med 2012: 965846, 2012.

14. Chung KS, Cho SH, Shin JS, Kim DH, Choi JH, Choi SY, Rhee YK, Hong HD and Lee KT: Ginsenoside Rh2 induces cell cycle arrest and differentiation in human leukemia cells by upregulating TGF- $\beta$ expression. Carcinogenesis 34: 331-340, 2013.

15. Yan XJ, Gong LH, Zheng FY, Cheng KJ, Chen ZS and Shi Z: Triterpenoids as reversal agents for anticancer drug resistance treatment. Drug Discov Today 19: 482-488, 2014.
16. Li S, Gao Y, Ma W, Guo W, Zhou G, Cheng T and Liu Y: EGFR signaling-dependent inhibition of glioblastoma growth by ginsenoside Rh2. Tumour Biol 35: 5593-5598, 2014.

17. Park EK, Lee EJ, Lee SH, Koo KH, Sung JY, Hwang EH, Park JH, Kim CW, Jeong KC, Park BK, et al: Induction of apoptosis by the ginsenoside Rh2 by internalization of lipid rafts and caveolae and inactivation of Akt. Br J Pharmacol 160: 1212-1223, 2010.

18. Maurer U, Preiss F, Brauns-Schubert P, Schlicher L and Charvet C: GSK-3 - at the crossroads of cell death and survival. J Cell Sci 127: 1369-1378, 2014.

19. Zhang JS, Herreros-Villanueva M, Koenig A, Deng Z, de Narvajas AA, Gomez TS, Meng X, Bujanda L, Ellenrieder V, Li XK, et al: Differential activity of GSK-3 isoforms regulates $\mathrm{NF}-\kappa \mathrm{B}$ and TRAIL- or TNF $\alpha$ induced apoptosis in pancreatic cancer cells. Cell Death Dis 5: e1142, 2014.

20. Gao Y, Liu Z,Zhang X, He J, Pan Y, Hao F, Xie L, Li Q, Qiu X and Wang E: Inhibition of cytoplasmic GSK-3 $\beta$ increases cisplatin resistance through activation of $\mathrm{Wnt} / \beta$-catenin signaling in A549/DDP cells. Cancer Lett 336: 231-239, 2013.

21. Lee H, Bae S, Kim YS and Yoon Y: WNT/ $\beta$-catenin pathway mediates the anti-adipogenic effect of platycodin $\mathrm{D}$, a natural compound found in Platycodon grandiflorum. Life Sci 89: 388-394, 2011

22. Thompson MD and Monga SP: WNT/beta-catenin signaling in liver health and disease. Hepatology 45: 1298-1305, 2007.

23. Mosimann C, Hausmann G and Basler K: Beta-catenin hits chromatin: Regulation of Wnt target gene activation. Nat Rev Mol Cell Biol 10: 276-286, 2009.

24. Ying Y and Tao Q: Epigenetic disruption of the WNT/beta-catenin signaling pathway in human cancers. Epigenetics 4: 307-312, 2009.

25. Chen L, Dai J, Wang Z, Zhang H, Huang Y and Zhao Y: Ginseng total saponins reverse corticosterone-induced changes in depression-like behavior and hippocampal plasticity-related proteins by interfering with GSK-3 $\beta$-CREB signaling pathway. Evid Based Complement Alternat Med 2014: 506735, 2014.

26. Fu M, Wang C, Rao M, Wu X, Bouras T, Zhang X, Li Z, Jiao X, Yang J, Li A, et al: Cyclin D1 represses p300 transactivation through a cyclin-dependent kinase-independent mechanism. J Biol Chem 280: 29728-29742, 2005.

27. Dahmani R, Just PA and Perret C: The Wnt/ $/$-catenin pathway as a therapeutic target in human hepatocellular carcinoma. Clin Res Hepatol Gastroenterol 35: 709-713, 2011.

28. Debeb BG, Lacerda L, Xu W, Larson R, Solley T, Atkinson R, Sulman EP, Ueno NT, Krishnamurthy S, Reuben JM, et al: Histone deacetylase inhibitors stimulate dedifferentiation of human breast cancer cells through WNT/ $\beta$-catenin signaling. Stem Cells 30: 2366-2377, 2012.

29. Correia AL, Mori H, Chen EI, Schmitt FC and Bissell MJ: The hemopexin domain of MMP3 is responsible for mammary epithelial invasion and morphogenesis through extracellular interaction with HSP90 $\beta$. Genes Dev 27: 805-817, 2013.

30. Wang X, Li F, Fan C, Wang C and Ruan H: Effects and relationship of ERK1 and ERK 2 in interleukin-1 $\beta$-induced alterations in MMP3, MMP13, type II collagen and aggrecan expression in human chondrocytes. Int J Mol Med 27: 583-589, 2011.

31. Konstantinopoulos PA, Karamouzis MV, Papatsoris AG and Papavassiliou AG: Matrix metalloproteinase inhibitors as anticancer agents. Int J Biochem Cell Biol 40: 1156-1168, 2008. 